\title{
Rotational Profile of Anteromedial Surface of Distal Tibia: A Computerized Tomography Study
}

\author{
Distal Tibia Anteromedial Yüzeyinin Rotasyonel Profili: Bilgisayarlı tomografi çalışması
}

Murat Songür ${ }^{1}$, Ercan Şahin ${ }^{1}$, Mehmet Ali Deveci ${ }^{2}$, ibrahim Illker Öz ${ }^{3}$, Ahmet Bayar ${ }^{1}$, Selçuk Keser ${ }^{1}$

${ }^{1}$ Bulent Ecevit University, Faculty of Medicine, Department of Orthopaedics and Traumatology, Zonguldak, Turkey

${ }^{2}$ Cukurova University, Faculty of Medicine, Department of Orthopaedics and Traumatology, Adana, Turkey

${ }^{3}$ Bulent Ecevit University, Faculty of Medicine, Department of Radiology, Zonguldak, Turkey

\section{ABSTRACT}

Background: Closed surgical treatment of long bone fractures by minimally invasive percutaneous plate osteosynthesis (MIPO) is prone to malrotation. In this study we aimed to determine the transverse plane torsional axis differences of medial surface of distal tibia and tibial diaphysis, involved in anatomical plate minimal invasive percutaneous osteosynthesis.

Materials and method: The computerized tomography (CT) images from PACS archive of computerized tomography unit of the institution were reviewed retrospectively. Tibia scans of forty male cases meeting inclusion and exclusion criteria were evaluated. The inclination of the plane of the surface of the tibia was measured. Plane of the surface is defined as axis of the surface of tibia involved in distal medial plating. Sections were measured starting from one centimeter proximal to the tip of medial malleolus and continued proximally in one centimeter intervals for next twenty-five sections. Results were analyzed after grouping the cases according to average stature (as below average and above average).

Results: At the level of $5^{\text {th }} \mathrm{cm}$. proximal to medial malleolus, approximately 13 o of external rotation of medial surface of tibia was noted. After $11-12^{\text {th }} \mathrm{cm}$ level, external rotation exceeds $20 \%$. At $16-19^{\text {th }} \mathrm{cm}$, amount of rotation reaches 30 . Change in the axis occurs more proximally in cases above average stature. More proximally amount of external rotation decreases gradually. At $26^{\text {th }} \mathrm{cm}$ level, a mean of 23.21 o of external rotation was measured. Amount of rotation did not differ according to stature.

Conclusion: Up to 30 of external rotational plane difference was observed notably after $17-20^{\text {th }} \mathrm{cm}$ from the tip of the medial malleolus. Inadvertent leaning of proximal extension of a straight/ untwisted anatomical distal tibial plate may result with significant external rotational malalignment, especially in comminuted fractures where fixation was extended towards tibial diaphysis.

Key Words: Distal tibia, Fracture, Anatomical plate osteosynthesis, MIPO, malrotation

Received: 12.21 .2017
Accepted: 04.10.2018

\section{ÖZET}

Amaç: Uzun kemik kırıklarının minimal invaziv perkütan plak yöntemi (köprü plaklama) ile tespiti, rotasyonel redüksiyon kusuru ile sonuçlanabilmektedir (malrotasyon). Bu çalışmada, distal tibia kırıklarında minimal invaziv köprü plaklama esnasında plak uygulanan kemik yüzeylerden distal tibia ve tibial diyafiz yüzeylerinin transvers düzlemdeki torsiyonel farklılıklarını belirlemeyi amaçladık.

Yöntemler: Hastanemiz PACS arşivi bilgisayarlı tomografi görüntü havuzu geriye dönük taranarak çalışmaya alınma kriterlerine uyan 40 erkek hastanın tibia BT görüntülerine ulaşıldı. Aksiyel plan görüntülerde plak uygulanan anteromedial yüzeyin eğimi ölçüldü. Ölçümler medial malleol tipinin $1 \mathrm{~cm}$. proksimalinden başlayarak proksimale birer $\mathrm{cm}$. aralıklarla toplam 26 kesitte (1 baseline- 25 kesit) devam edildi. Ölçülen değerler olguların ortalama boyun altında veya üzerinde olma durumlarına göre tekrar gruplanması sonrası analiz edildi.

Bulgular: Medial malleol seviyesinin $5 \mathrm{~cm}$. proksimalinden itibaren yüzeyde distaldeki ilk başlangıç noktasına göre yüzeyin eğiminin yaklaşık $13^{\circ}$ dış rotasyon yönünde farklılık gösterdiği görülmüştür. Bu farklılık $11-12 \mathrm{~cm}$. seviyesinde 20\%yi geçmiş olup $16-19 \mathrm{~cm}$ seviyelerinde $30^{\circ}$ ye ulaştığı gözlenmiştir. Daha proksimalde ise eğimin azaldığı ve en proksimal ölçüm kesiti olan medial malleolün $26 \mathrm{~cm}$ proksimalinde ise ortalama $23,21^{\circ}$ bir dış rotasyon yönünde düzlem farkı gözlenmiştir. Rotasyon miktarı boya göre farklılık göstermemiştir.

Sonuç: Distal tibianın anteromedial yüzeyinde, medial malleolün $17-20 \mathrm{~cm}$ proksimalinde en belirgin olmak üzere $30^{\circ}$ ye varan dış rotasyon yönünde yüzey torsiyonunda farklılılar gözlenmektedir. Bu farklılık köprü plaklama yaparken düz bir plak kullanımı esnasında plağın yerleştirilmesi ve kemiğe tespiti esnasında dikkat edilmesi gereken bir faktör olarak karşımıza çıkmaktadır. Özellikle kırık hattının proksimale uzandığı veya parçalı kııılarda düz /anatomik torsiyonu olmayan bir plağın köprü plaklama esnasında yüzeye tamamen yaslanarak tespiti, belirgin dış rotasyon dizilim bozukluğuna neden olabilecektir.

Anahtar Sözcükler: Distal tibia, kırık, anatomik plak tespiti, MiPO, malrotasyon

Geliş Tarihi: 21.12.2017

Kabul Tarihi: 10.04.2018 


\section{INTRODUCTION}

Minimally invasive percutaneous plate osteosynthesis (MIPO) with locking anatomical plates became the choice of treatment of both extra- and intraarticular distal tibial fractures (1). With indirect reduction techniques utilizing c-arm imaging, combined with bridge plating without exposing the fracture site, successful results were reported (2-4). Despite modern imaging and fixation techniques, malrotation in closed treatment of fractures of tibia is still a concern. Although malrotation is a major problem of intramedullary nailing of tibial shaft fractures with incidences up to $20-30 \%(5,6)$, rotational malpositioning during MIPO plating of tibia were also reported (7-10). Due to proximity to ankle and relative stabilizing effect of fibula, malrotation following MIPO of distal tibial fractures is not reported or investigated into account in previous case series published in literature, until the study published by Sitnik et al. Twenty-five percent malrotation exceeding $10^{\circ}$ was reported after MIPO of distal tibial fractures (3). Especially in comminuted fractures, it may be challenging to restore rotational alignment of fracture fragments.

Various manufacturers have introduced distal tibia anatomical plates to be used with MIPO principles. To avoid implant prominence and skin problems, perfect fit is desired in distal fixation of the plate under imaging control in sagittal and coronal plane. During fixation of proximal fragment, plate fit is not taken into consideration. When using long plates extending towards tibial diaphysis, significant rotational mismatch may occur with the plane of the plate and anteromedial tibial surface involved during bridge plating. If proximal extension of a straight plate $(3.5 \mathrm{~mm}$. Synthes distal tibia LCP plate) is erroneously fit over anteromedial surface of tibia, significant rotational malalignment and displacement may occur (Figure 1).

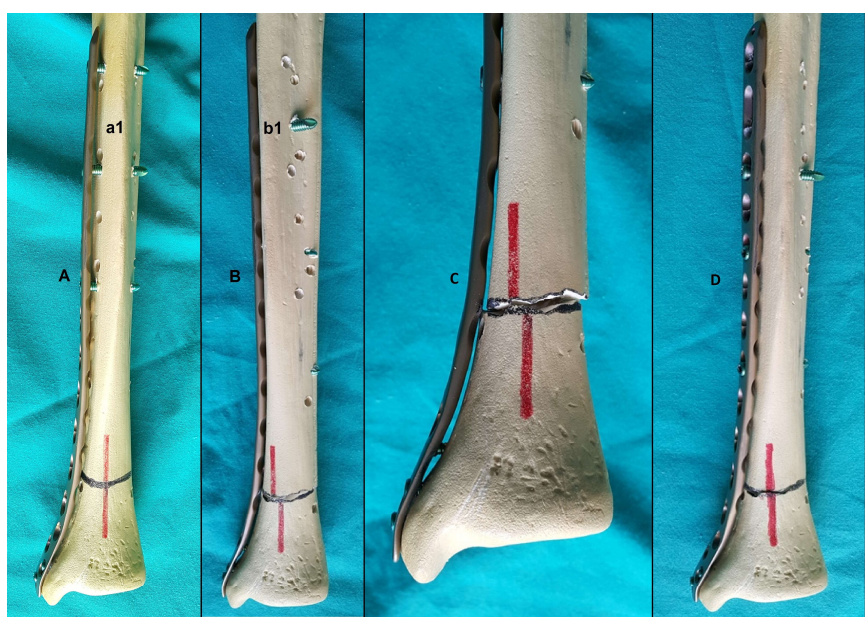

Figure 1: (A) Distal medial anatomic plate application on saw bone model. Application without modification of the plate. Note the incongruence between the proximal extension of the plate and the tibial diaphysis (a1). If proximal extension of the plate is erroneously leant over anteromedial surface of tibia diaphysis (B) and secured (b1), distal fragment rotates externally (C). If proximal extension of the plate is twisted according to anteromedial surface of tibial diaphysis and secured by leaning, malrotation of the fracture site is not observed (D).

In this study we aimed to define the transverse plane rotational differences of the medial and antero-medial surfaces of tibia, involved in MIPO plating of distal tibial periarticular fractures, from a set of computerized tomography images and emphasize the possible importance in establishment of rotational alignment during surgical treatment of distal tibia fractures.

\section{MATERIALS and METHODS}

The images to be evaluated were extracted from PACS archive of CT unit of Bulent Ecevit University, department of radiology. The CT images were taken for routine clinical diagnostic purposes. Indications for CT included; trauma, soft tissue problems and possible neoplastic and infectious processes. Out of 860 extremity scans performed between years 2012 and 2015, 124 patients had tibial CT images scanned from ankle (tip of the malleolus) towards tibial diaphysis. Exclusion criteria were defined as; children and adolescents younger than 18 years of age, displaced fracture, neoplasia and other dysplastic and traumatic conditions (post-operative images etc.) changing the bony architecture of tibia. After exclusion, a total of 52 scans could be achieved (40 M, 12F). Due to discrepancy of stature and limited number, female cases were also excluded to ensure homogeneity.
The images were processed and angular measurements were made by use of PACS software of the institution (MIAMED, MIA Technology, Ankara /TURKEY). The age and height of patients were retrieved from hospital registry data.

Rotational plane difference of medial surface of tibia (distally) and anteromedial surface of tibia (proximally) is the main outcome measurement. The plane of the surface was designated as the line connecting the anterior and posterior margin of medial surface of tibia. The surface between fascial attachments is the surface involved in medial bridge plating of distal tibial fractures. Therefore margins of the surface were accepted as the points of fascial attachments both anteriorly and posteriorly. Torsional profile of anteromedial surface of tibia is evaluated similarly to femoral anteversion measurement using CT (11). The inclination of the plane of the surface of tibia relative to horizontal was measured and recorded for consecutive levels of each scan (Figure 2). First level to be measured was the section $1 \mathrm{~cm}$. proximal to the tip of medial malleolus, and accepted as baseline. This level is the level where distal end of the plate was usually fitted. Following images are taken every $1 \mathrm{~cm}$. proximally (Figure 3). A total of 26 images could be measured for every patient. The result of the subtraction of inclination of each level (Inclevel) from inclination of baseline ( $\left.I \mathrm{nc}^{\text {Baseline }}\right)$ revealed the angular

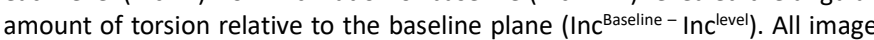
processing and measurements were performed by two consecutive observers (MS and ES). All data was analyzed statistically for inter-observer measurement variations and mean change in rotational axis of surfaces. Inter-observer measurement agreement and significance was determined using Bland-Altman plots for each measured level.

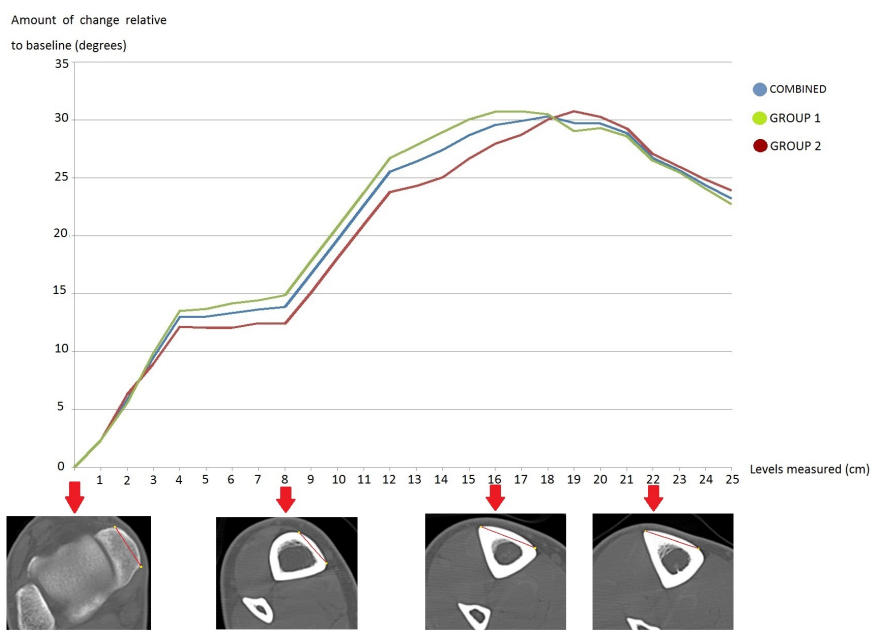

Figure 2: Landmarks to define surface of tibia on CT image. Tibial surface involved in bridge plating is bordered anteriorly and posteriorly by fascial attachments ( $a$ and $b$ ). Line connecting these two points is accepted as the plane of that level.

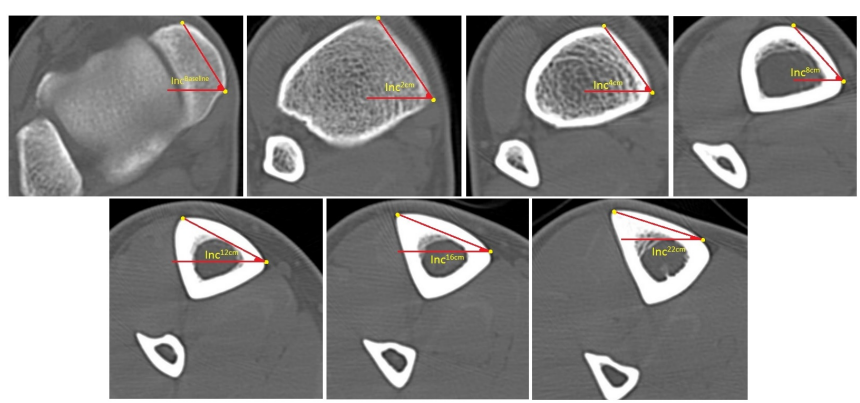

Figure 3: CT sections showing the plane of different sections of tibia. Each level was measured individually. Change in the axis is defined as subtraction of inclination of that level from inclination of the baseline (Inc ${ }^{\text {Baseline - Inclevel). }}$. Note the gradual decrease of inclination, therefore increase in external rotation of the plane of the surface of the tibia proximally.

To homogenize study population, subjects were regrouped according to the average stature of study population (Turkish male subjects) (12). Mean stature of adult male population was reported as $174.6 \pm 9.1 \mathrm{~cm}$. Then cases were regrouped according to stature less than $174 \mathrm{~cm}$. as group $1(\mathrm{n}=24)$ and above $174 \mathrm{~cm}$. as group $2(\mathrm{n}=16)$. Differences in change of the inclinations of surfaces between groups were analyzed with Mann-Whitney-U test. 


\section{RESULTS}

Age and stature details of study population were given in Table 1. Mean age of cases was $34.5 \pm 9.78$ years. Average stature of cases was calculated as $173.55 \pm 4.88 \mathrm{~cm}$. Approximately $8 \mathrm{~cm}$. of difference was observed between mean statures of groups. Starting from baseline and continuing proximally, an external rotation of the plane of medial surface of tibia was noted (Figure 3).

Table 1. Study population details.

\begin{tabular}{lcc}
\hline Study population & Age $(\mathrm{yrs})$. & \multicolumn{1}{c}{ Stature $(\mathbf{c m})}$. \\
\hline Overall $(\mathrm{n}=\mathbf{4 0})$ & $34.5 \pm 9.78$ & $173.55 \pm 4.88$ \\
Group 1 & $35.16 \pm 8.67$ & $170.25 \pm 2.02$ \\
Stature $\leq \mathbf{1 7 4} \mathbf{c m} .(\mathrm{n}=\mathbf{2 4})$ & & \\
Group 2 & $33.5 \pm 11.83$ & $178.5 \pm 3.39$ \\
Stature $>\mathbf{1 7 4} \mathbf{c m}(\mathbf{n}=\mathbf{1 6})$ & & \\
\hline
\end{tabular}

This rotation was measured as the decrease in the inclination of the plane of that level. Amount of decrease relative to baseline on each level was detailed in Table 2. At the level of $4^{\text {th }} \mathrm{cm}$. proximal to baseline $(5 \mathrm{~cm}$. proximal to medial malleolar tip), approximately 13 o of external rotation of medial surface of tibia was noted. After $10^{\text {th }} \mathrm{cm}$. level in group 1 and $11^{\text {th }} \mathrm{cm}$. level in group 2, the amount of external rotation exceeded $20 \%$. At $15^{\text {th }} \mathrm{cm}$ in group 1 and $18^{\text {th }} \mathrm{cm}$ in group 2, amount of external rotation reaches 30․ Maximal amount of rotation was measured at $17^{\text {th }}$ level as $30.75^{\circ}$ in group 1 and at $19^{\text {th }}$ level as $30.78^{\circ}$ in group 2. There was no difference regarding the maximal amount of external rotation between groups. At following sections proximally, it decreased gradually. At $25^{\text {th }} \mathrm{cm}$ level, mean external rotation was recorded as 23.210 . As expected, due to decreased tibial length, the increase in external rotation started more distally in group 1 compared to group 2. In majority of levels (except levels 1, 18, 20, 21, 22 and 23) the differences between group 1 and 2 were significant. The results of combined measurements of groups 1 and 2 were also detailed in table 2. The change in the inclination of each level was demonstrated as a graph in Figure 4.

Table 2. Details of the amount of decrease in the inclination of the plane of tibial surface relative to baseline.

\begin{tabular}{|c|c|c|c|c|c|c|c|c|c|c|c|c|c|c|c|c|c|c|c|c|c|c|c|c|c|c|}
\hline & & \multicolumn{25}{|c|}{ Levels proximal to baseline in $1 \mathrm{~cm}$ intervals } \\
\hline & & $1^{\text {st }}$ & $2^{\text {nd }}$ & $3^{\text {rd }}$ & $4^{\text {th }}$ & $5^{\text {th }}$ & $6^{\text {th }}$ & $7^{\text {th }}$ & $8^{\text {th }}$ & $9^{\text {th }}$ & $10^{\text {th }}$ & $11^{\text {th }}$ & $12^{\text {th }}$ & $13^{\text {th }}$ & $14^{\text {th }}$ & $15^{\text {th }}$ & $16^{\text {th }}$ & $17^{\text {th }}$ & $18^{\text {th }}$ & $19^{\text {th }}$ & $20^{\text {th }}$ & $21^{\text {st }}$ & $22^{\text {nd }}$ & $23^{\text {rd }}$ & $24^{\text {th }}$ & $25^{\text {th }}$ \\
\hline \multirow{7}{*}{$\begin{array}{l}\text { Amount of } \\
\text { external } \\
\text { rotation } \\
\text { relative to } \\
\text { baseline } \\
\left({ }^{\circ}\right)\end{array}$} & Group 1 & 2.39 & 5.60 & 9.87 & 13.54 & 13.69 & 14.17 & 14.43 & 14.87 & 17.81 & 20.75 & 23.75 & 26.73 & 27.83 & 28.98 & 30.06 & 30.71 & 30.75 & 30.52 & 29.06 & 29.31 & 28.60 & 26.52 & 25.52 & 24.08 & 22.72 \\
\hline & $S D^{*}$ & 0.36 & 0.46 & 0.42 & 0.53 & 0.62 & 0.69 & 0.56 & 0.56 & 0.62 & 0.83 & 0.75 & 0.82 & 0.94 & 0.77 & 0.65 & 0.53 & 0.53 & 1.00 & 0.65 & 1.70 & 1.62 & 1.04 & 0.95 & 0.73 & 0.59 \\
\hline & Group 2 & 2.41 & 6.31 & 8.97 & 12.16 & 12.06 & 12.09 & 12.47 & 12.43 & 15.09 & 18.09 & 20.97 & 23.78 & 24.31 & 25.06 & 26.69 & 27.94 & 28.75 & 30.06 & 30.78 & 30.28 & 29.28 & 27.09 & 25.97 & 24.87 & 23.94 \\
\hline & $S D^{*}$ & 0.52 & 0.44 & 0.34 & 0.44 & 0.51 & 0.52 & 0.50 & 0.60 & 0.95 & 0.90 & 0.74 & 0.75 & 0.57 & 0.57 & 0.65 & 0.77 & 0.89 & 1.03 & 0.55 & 0.89 & 1.03 & 0.97 & 0.69 & 0.62 & 0.44 \\
\hline & p-value ${ }^{* z}$ & 0.81 & $<0.05$ & $<0.05$ & $<0.05$ & $<0.05$ & $<0.05$ & $<0.05$ & $<0.05$ & $<0.05$ & $<0.05$ & $<0.05$ & $<0.05$ & $<0.05$ & $<0.05$ & $<0.05$ & $<0.05$ & $<0.05$ & 0.24 & $<0.05$ & 0.07 & 0.21 & 0.09 & 0.11 & $<0.05$ & $<0.05$ \\
\hline & $\begin{array}{l}\text { Combined } \\
\text { (group 1 \& } \\
2 \text { ) }\end{array}$ & 2.40 & 5.89 & 9.51 & 12.99 & 13.04 & 13.34 & 13.65 & 13.90 & 19.72 & \begin{tabular}{|l|l|}
19.69 \\
\end{tabular} & 22.64 & 25.55 & 26.42 & 27.41 & 28.71 & 29.60 & 29.95 & \begin{tabular}{l|l|l} 
& 0.34 \\
\end{tabular} & 29.75 & $\begin{array}{l}29.70 \\
\end{array}$ & 28.87 & 26.75 & 25.70 & 24.40 & 23.21 \\
\hline & $\mathrm{SD}^{*}$ & 0,43 & 0,57 & 0,59 & 0,84 & 0,99 & 1,20 & 1,11 & 1,33 & 1,55 & 1,57 & 1,56 & 1,66 & 1,92 & 2,06 & 1,79 & 1,51 & 1,21 & 1,03 & 1,04 & 1,50 & 1,44 & 1,04 & 0,87 & 0,79 & 0,80 \\
\hline
\end{tabular}

* SD: Standard deviation.

** $\mathrm{p}$ - value was defined to determine the significance between groups 1 and 2 .

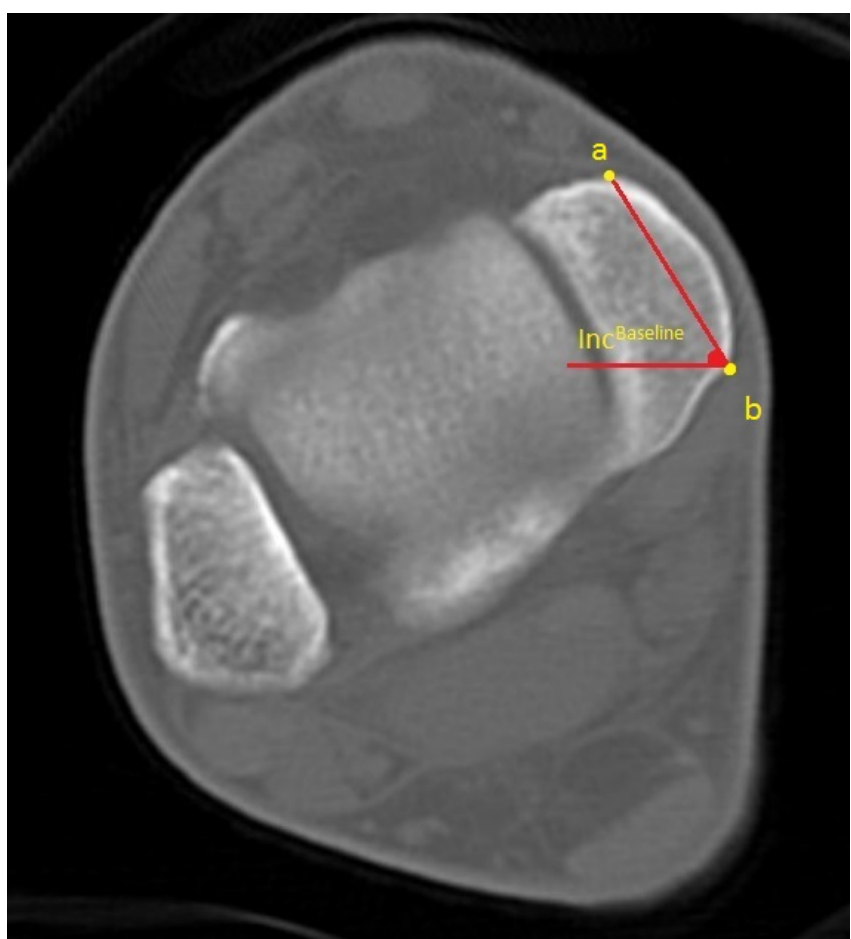

Figure 4: Graph showing the change in the transverse plane axis of the anteromedial surface of the tibia relative to baseline.

Inter-observer measurement variation was analyzed using Bland-Altman method. Significant measurement differences were observed at $9^{\text {th }}, 11^{\text {th }}, 17^{\text {th }}$, $18^{\text {th }}, 20^{\text {th }}$ and $21^{\text {st }}$ levels $(p<0.05)$. Overall measurement variation in those levels ranged between $-2.25^{\circ}$ and $+1.32^{\circ}$, summing a 3.57 degrees of maximal measurement variation. The measurement variation in remaining levels was insignificant.

\section{DISCUSSION}

Rotational positioning during MIPO of distal tibial fractures may be challenging if fracture is comminuted and when fibula is not involved in alignment of the limb. Up to $25 \%$ rotational malpositioning was observed exceeding $10^{\circ}(3)$. In general distal tibial malrotation is not accepted as a major concern. Very few studies are available regarding acceptable malrotation of distal tibia affecting ankle joint functions. In a cadaveric study, Svoboda et al. reported altered ankle biomechanics when rotational malalignment exceeds $20^{\circ}$ (13). Conversely, Theriault et al. reported similar intermediate-term lower extremity functional scores in patients with or without malrotation following tibial intramedullary nailing (14). Whereas, van der Werken and Marti recommended correction for deformities exceeding $20^{\circ}$ external and $15^{\circ}$ internal malrotation, from the results of their case series (15). In this study, we aimed to investigate the torsional axis change of the medial surface of distal tibia and antero-medial surface of tibial diaphysis involved in MIPO plating. We observed a significant torsional change reaching 30 o at about $16-19 \mathrm{~cm}$. proximal to the tip of the medial malleolus. Inadvertent leaning and fitting of proximal extend of a straight (un-twisted) plate on tibial diaphysis may result with a significant rotational mismatch between proximal and distal fragments, especially in comminuted fractures. Even after eliminating the possible side variations of tibial torsion $\left(2.5^{\circ}-4^{\circ}\right)$ reported in the literature $(16,17)$ and measurement variations calculated in this study $\left(3.57^{\circ}\right)$, still a remarkable difference exists. Therefore we believe that, rotational axis change of tibial surfaces must be taken into consideration during bridge plating of distal tibial fractures.

Plate-bone congruency in distal tibial anatomical plate osteosynthesis was reported to vary between $43-62 \%$ of cases (18). Also, a perfect bone-implant fit is not a demanded factor in percutaneous plating using locked plates, in conjunction with the internal fixator philosophy of modern fracture treatment protocols which involves load transfer through shear force coupled by screw heads (19). 
But minimizing the distance between plate and bone surface not only minimizes implant prominence on the skin, also help to improve screw-plate biomechanics. Rotational malpositioning can be avoided by four ways: (1) Preoperative imaging of uninvolved side. (2) Plate may be rotated/twisted externally 20 을 approximately $10-11 \mathrm{~cm}$. from the tip of the plate, and twisting may be increased to $25-30$ degrees after $15-18^{\text {th }} \mathrm{cm}$. before spanning through fracture fragments. Such a modification not only increase plate-bone conformity, but also may help in reduction of fragments and may facilitate alignment. Although minor bending and torsions rarely damage screw holes, significant and acute bending and twisting of locking plates may interrupt screw head- plate fixation and may result with hardware failure and thus not recommended $(20,21)$. (3) Using pre-contoured / twisted distal medial anatomical plates. (4) Fixation of the proximal fragment without leaning of plate to tibial diaphysis by locking screws, also without twisting the plate, being aware of the rotational profile of the bony surfaces. But in this case, contact mismatch of 20-30 degrees between plate and anteromedial tibial surface of diaphysis may have a negative influence on construct stiffness.

Our study has some limitations. Due to limited number of cases, these findings do not represent the whole population; therefore cannot be generalized and accepted as descriptive. Studies with bigger samples including gender and racial variations should be made. The aim of this study is not to define a specific torsional profile of the anteromedial surface of distal tibia. Specific topographic evaluation of surfaces of tibia involved during internal fixation may be performed using whole tibia CT or 3D scanning instruments on cadaver bones. We aimed to provide an insight about the torsional profile change of tibia for future studies and avoid rotational malposition especially in comminuted fractures, when proximal extension of the plate is extended to tibial diaphysis. Further clinical and radiological follow-up studies investigating importance of distal tibial axial plane alignment are necessary.

\section{CONCLUSION}

Transverse plane profiles of medial and anteromedial surface of tibia involved in minimally invasive percutaneous plate osteosynthesis (MIPO) are subject to change. Stature also has influence on the level of change, but has no change on overall change. Awareness of the rotational variation of tibial surfaces involved during locked bridge plate osteosynthesis, may avoid external rotational malpositioning.

\section{Acknowledgements:}

Authors wish to thank Dr. Mustafa Cagatay Buyukuysal for his contribution on the statistical analyses of the study.

\section{Conflict of interest}

No conflict of interest was declared by the authors.

\section{REFERENCES}

1. Khalsa AS, Toossi N, Tabb LP, Amin NH, Donohue KW, Cerynik DL. Distal tibia fractures: locked or non-locked plating? A systematic review of outcomes. Acta Orthop 2014; 85: 299-304.

2. Helfet DL, Shonnard PY, Levine D, Borrelli J Jr. Minimally invasive plate osteosynthesis of distal fractures of the tibia. Injury 1997; 28 Suppl 1: A42-7; discussion A47-8.
3. Sitnik AA, Beletsky AV. Minimally Invasive Percutaneous Plate Fixation of Tibia Fractures: Results in 80 Patients. Clin Orthop Relat Res 2013; 471: 2783-9.

4. Paluvadi SV, Lal H, Mittal D, Vidyarthi K. Management of fractures of the distal third tibia by minimally invasive plate osteosynthesis - A prospective series of 50 patients. J Clin Orthop Trauma 2014; 5: 12936.

5. Puloski S, Romano C, Buckley R, Powell J. Rotational malalignment of the tibia following reamed intramedullary nail fixation. J Orthop Trauma 2004; 18: 397-402.

6. Jafarinejad AE, Bakhshi $\mathrm{H}$, Haghnegahdar M, Ghomeishi N. Malrotation following reamed intramedullary nailing of closed tibial fractures. Indian J Orthop 2012; 46: 312-6.

7. Cole PA, Zlowodzki M, Kregor PJ. Treatment of proximal tibia fractures using the less 455 invasive stabilization system: surgical experience and early clinical results in 77 fractures. J Orthop Trauma 2004; 18: 528-35.

8. Ricci WM, Rudzki JR, Borrelli Jr J. Treatment of complex proximal tibia fractures with the less invasive skeletal stabilization system. J Orthop Trauma 2004; 18: 521-7.

9. Stannard J, Wilson TC, Volgas DA, Alonso JE. The less invasive stabilization system in the treatment of complex fractures of the tibial plateau: short-term results. J Orthop Trauma 2004; 18: 552-8.

10. Buckley R, Mohanty K, Malish D. Lower limb malrotation following MIPO technique of distal femoral and proximal tibial fractures. Injury, Int. J. Care Injured 2011; 42: 194-9.

11. Liodakis E, Doxastaki I, Chu K, Krettek C, Gaulke R, Citak M, Kenawey M. Reliability of the assessment of lower limb torsion using computed tomography: analysis of five different techniques. Skeletal Radiol 2012; 41: 305-11.

12. Duyar I, Pelin C. Body height estimation on tibia length in different stature groups. Am J Phys Anthropol 2003; 122: 23-7.

13. Svoboda SJ, McHale K, Belkoff SM, Cohen KS, Klemme WR. The effects of tibial malrotation on the biomechanics of the tibiotalar joint. Foot Ankle Int 2002; 23: 102-6.

14. Theirault $B$, Turgeon AF, Pelet $S$. Functional impact of tibial malrotation following intramedullary nailing of tibial shaft fractures. J Bone Joint Surg Am 2012; 94: 2033-9.

15. Van der Werken $C$, Marti RK. Post-traumatic rotational deformity of the lower leg. Injury 1983; 15: 38-40.

16. Strecker W, Keppler $\mathrm{P}$, Gebhard F, Kinzl L. Length and torsion of the lower limb. J Bone Joint Surg Br 1997; 79: 1019-23.

17. Sayli U, Bölükbasi S, Atik OS, Gündogdu S. Determination of tibial torsion by computed tomography. J Foot Ankle Surg 1994; 33: 144-7.

18. Schmutz B, Wullschleger ME, Kim H, Noser H, Schütz MA. Fit assessment of anatomic plates for the distal medial tibia. J Orthop Trauma 2008; 22: 258-63.

19. Tepic S, Remiger AR, Morikawa K, Predieri M, Perren SM. Strength recovery in fractured sheep tibia treated with a plate or an internal fixator: an experimental study with a two-year follow-up. J Orthop Trauma 1997; 11: 14-23.

20. Szypryt $P$, Forward D. The use and abuse of locking plates. Orthop Trauma 2009; 23: 289-90.

21. Wagner M. General principles for the clinical use of the LCP. Injury 2003; 34(Suppl. 2): 31-42. 